\title{
A Scale to Measure the Attitude of Marginal Farmers on Organic Farming
}

\author{
Gitasree Goswami* and Manju Dutta Das \\ Department of Extension and Communication Management, \\ Faculty of Community Science, AAU, Jorhat, India
}

*Corresponding author

\begin{tabular}{|l|}
\hline Ke y w o r d s \\
$\begin{array}{l}\text { Attitude, Organic } \\
\text { farming, Marginal } \\
\text { farmer, Scale }\end{array}$ \\
\hline Article Info \\
\hline $\begin{array}{l}\text { Accepted: } \\
\text { 10 July 2019 } \\
\text { Available Online: } \\
\text { 10 August } 2019\end{array}$ \\
\hline
\end{tabular}

A B S T R A C T

The present study was aimed to construct, develop and standardize an Attitude Scale on organic farming for marginal farmers. After going through several related literature, the researcher outlined a scale and after analyzing, the content framed 52 items related to the course. The prepared 52 items were revised and edited carefully and then given to a total 20 numbers of panel of experts in the field of entomology, horticulture, agronomy, soil science, rice research centre and extension specialist for their valuable suggestions and corrections to ensure its quality. After seeking the opinion of the experts some of the items were reframed. Finally, a total of 14 statements were prepared, for which 'Likert method of summated ratings' was followed. And these statements were administered to the 30 numbers of farmer from non-sample area from two villages each covering of 15 farmers. The list of 14 Statements ( 7 positive and 7 negative) were selected based on the ' $t$ ' values obtained from the item analysis.

\section{Introduction}

Increasing the use of chemical fertilizer declines soil fertility, plant nutrition as well as health of human body. It has encouraged the use of organic amendments for soil nutrient improvement which is getting importance these days for sustainable productivity and soil nutrient management. Recent studies have focused on re-considering traditional fertilization practices to enhance soil organic input by amendments of crop residues, biofertilizers, green manure, enriched compost and farmyard manure. In Assam, land occupied by marginal farmer is very limited as compared to big farmer which is less than 1 hectare. This may happen due to disintegration of families for which they are forced to live in nuclear family and can use very small land holding for agriculture. As marginal farmer's land holding is in between $0.50-1.00$ hectare only, they are unable to afford hi-tech systems for agricultural production. But it has been observed that as marginal farmers are agricultural farmers, they have some inherent skills with them. 
They produce limited agricultural products to meet the need of their families only but not capable of selling it in local markets to earn some capital as surplus.

In marginal families, it is a fact that both men and women involve in agricultural production activities. They are always eager to use chemical fertilizers to increase the production of agricultural crops for their food security. But due to lack of adequate money and poor access to extension services they are unable to apply the proper method of scientific technology in their field. Organic farming not only fulfil the requirements of family consumption but also give fair amount of income and reduce the cost of cultivation with a sustainability of agro eco system. There is a wide scope of organic farming which generates rural employment, provides food security at the house hold level, offer best prospects for poverty reduction and sustainable livelihood outcomes with maximum utilization of local natural inputs. For marginal farmers, organic farming can be a simple, cost effective, convenient and noiseless pathway. It also saves water, energy, landfills and helps to rebuild the soil too.

Hence, to increase the production of agricultural crops and ensures livelihood security of marginal families; attitude of marginal farmer on organic farming has to be positive. To create this positive attitude around the marginal farmers, intervention programmes need to be conducted; which in turn will help them to improve their attitude level on organic farming. Therefore, the researcher has decided to make an attempt to construct and standardize the Attitude Scale on organic farming for marginal farmers.

\section{Materials and Methods}

The method of summated rating suggested by Likert (1932) was followed in the development of scale to measure the attitude of farmer towards the organic farming. A total of 52 statements, expressing the attitude of farmers towards the organic farming were collected based on the applicability of statements to study area. For this study 30 farmers were selected from two non-sample villages each covering of 15 farmers. The responses were obtained on a five point continuum viz. - Strongly Agree (SA), Agree (A), Undecided (UD), Disagree (DA) and Strongly Disagree (SDA) with a score of 5, 4, 3,2 and 1 respectively for the positive statement and for the negative statement reverse scoring was adopted. The respondents were arranged in descending order based on the obtained score for each and every statement. After that criterion group was selected, i.e. 25 per cent of the respondents having the high score and 25 per cent of the respondents having the low score were taken. The ' $t$ ' value for each statement was calculated by using the following formula given by Edwards (1969).

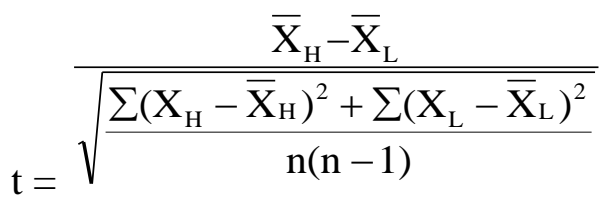

Where,

$\mathrm{t}=$ the extent to which a given statement differentiates between the high and low groups,

$\overline{\mathrm{X}}_{\mathrm{H}}=$ the mean score on a given statement for the high group,

$\bar{X}_{L}=$ the mean score on the same statement for the low group,

$\sum\left(\mathrm{X}_{\mathrm{H}}-\overline{\mathrm{X}}_{\mathrm{H}}\right)^{2}=$ the variance of the distribution of responses of the high group to the statement, 
$\sum\left(\mathrm{X}_{\mathrm{L}}-\overline{\mathrm{X}}_{\mathrm{L}}\right)^{2}=$ The variance of the distribution of responses of the low group to the statement

$\mathrm{n}(\mathrm{n}-1)=$ number of subjects in low or high group;

The statements finally retained in the scale, having ' $t$ ' value equal to or more than 1.75 , significant at 5 per cent level. Based on this criterion, 14 statements were filtered out leaving 7 positive and 7 negative statements were selected for inclusion in the attitude scale.

\section{Results and Discussion}

\section{Reliability of the scale}

The reliability of the attitude scale was tested in two ways namely split half technique and test-retest technique. In the split half technique the 14 statements were divided into two parts, 7 even numbers in one part and 7 odd numbers in the other part. These two sets of statements were administered to 30 respondents separately and their responses were recorded. Correlation coefficient when calculated between the two sets of scores thus obtained was found highly significant (0.89) which indicated high degree of internal consistency of the attitude scale.

In the test retest technique the ten statements were administered twice to 30 respondents at an equal interval of 20 days. The co- efficient of correlation obtained between these sets of scores, was also highly significant (0.87) thus revealing high reliability of the scale (Table 1 and 2).

\section{Validity of the scale}

For testing the validity of the scale, content validity was considered. Since the statements of these attitude scales were derived from a long list of opinions and from literature, the statements reflected varied attitudes representing the universe. Therefore, the scale could be considered as having content validity.

Table.1 The statements of item analysis by farmers of non-sample area

\begin{tabular}{|c|l|}
\hline Sl. No. & \multicolumn{1}{|c|}{ ITEMS } \\
\hline 1. & Organic fertilizers are more suitable to control pest in organic farming \\
\hline 2. & Organic farming is troublesome for the farmers as it needs more attention \\
\hline 3. & Improves the quality of soil and water conservation \\
\hline 4. & Farmers are interested to produce organic products due to high market demand \\
\hline 5. & Keeps environment free from pollution \\
\hline 6. & There is less demand in organic products due to absence of certification \\
\hline 7. & The shifting from traditional farming to organic farming is very difficult \\
\hline 8. & Organic planting materials are not available for organic farming \\
\hline 9. & Can be done without application of chemical fertilizers, pesticides and insecticides \\
\hline 10. & Organic farming needs more labour \\
\hline 11. & Organic products are affordable \\
\hline 12. & Organic farming can meet the demand of the consumers \\
\hline 13. & There is a risk in production of organic farming \\
\hline 14. & Has the less risk of environmental pollution \\
\hline
\end{tabular}


Table.2 Scoring techniques of the scale

\begin{tabular}{|c|c|}
\hline Category & Score Range \\
\hline Low & Below $(\overline{\mathrm{X}}-\mathrm{Sd})$ \\
\hline Medium & $\overline{\mathrm{X}}-\mathrm{Sd}$ to $\overline{\mathrm{X}}+\mathrm{Sd}$ \\
\hline High & Above $\overline{\mathrm{X}}+\mathrm{Sd}$ \\
\hline
\end{tabular}

\section{Scoring techniques of the scale}

The final scale consisted of 14 statements (7 positive and 7 negative). Extension personnel's responses were recorded on a five point continuum as Strongly Agree (SA), Agree (A), Undecided (UD), Disagree (DA) and Strongly Disagree (SDA). Scores were given to positive statement as 5, 4, 3,2,1 and for negative statement $1,2,3,4$ and 5 .

Based on mean $(\overline{\mathrm{X}})$ and standard deviation (SD) of the obtained attitude scores, respondents were classified into three categories as:

It is concluded that the attitude scale was developed and standardized with a total of fourteen (14) items with both positive and negative statements on organic farming. The developed and standardized Attitude Scale was valid and reliable. Hence, the scale could serve the purpose for assessing the organic farming for marginal farmers.

\section{References}

Ashraf, I., Ahmad, I., Nafees, M., Yousaf, M. M. and Ahmad , B. ( 2016) Organic farming for sustainable agricultural production. Bolan Society for Pure and Applied Biology.

Azam, S. and Banumathi, M. (2015). The role of demographic factors in adopting organic farming: A logistic model approach. International journal of advanced research. 3(8): 713 - 720
Burch et al.,(2008) Socio-economic effects of organic agriculture in Africa. $16^{\text {th }}$ IFOAM Organic World Congress.

Haque, T. (2017) Diversification of small farms in India: problems and prospects. National Centre for Agricultural Economics and Policy Research.

Kiran, D. D., Gupta, K. B., Pandey, K. D. and Upadhaya, D.A. (2012) Empowerment of Rural Women in Agriculture: A Socio-psychological Analysis. Stud. Home. Com. Sci. 6(3): 139-144

Kumar, K. (2016) A Scale to Measure Attitude of Farmers' towards Organic Farming. Indian Res. J. Ext. Edu. 16 (1): 148

Marsh, L., Zoumenou,V., Cotton, C. and Hashem, F. ( 2016) Organic farming: knowledge, practices, and views of limited resource farmers and nonfarmers on the Delmarva Peninsula. Org. Agriculture. 7: 125-132

Meenakumari, T. and Shekhar, M. (2012) Biotechnological solid waste management by vermicomposting. World Research Journal of Agricultural Biotechnology. 1 (1): 01-03

NPCS Board of Consultants \& Engineers (2008) The Complete Book on Organic Farming and Production of Organic Compost. Asia Pacific Business Press Inc.

Palaniappan, P. S. and Annadurai, K. (2006) Organic Farming Theory and Practice. Scientific publishers of India.

Rayanagouda, R. (2012) Knowledge level of farm women about organic farming and organic foods. Karnataka J. Agric. Science. 25 (2): 298-300 
Udin, N. (2014) OrganicFarming Impact on Sustainable Livelihoods of Marginal Farmers in Shimoga District of Karnataka. American Journal of Rural Development. 2(4): 81-88
Steven, Lebailly and Philippe (2017) Organic Farming and Small-Scale Farmers: Main Opportunities and Challenges. 132: 144-154.

Zeynab, J., Hossein, A., Fatemeh, T., Kiumars, Z., Kindeya, G., Passel, V.,

\section{How to cite this article:}

Gitasree Goswami and Manju Dutta Das. 2019. A Scale to Measure the Attitude of Marginal Farmers on Organic Farming. Int.J.Curr.Microbiol.App.Sci. 8(08): 1029-1033.

doi: https://doi.org/10.20546/ijcmas.2019.808.119 